\title{
FACTORS FAVORING AMARANTH CONSUMPTION IN MEXICO CITY: CASE STUDY XOCHIMILCO
}

\section{FACTORES OUE FAVORECEN EL CONSUMO DE AMARANTO EN LA CIUDAD DE MÉXICO: CASO DE ESTUDIO XOCHIMILCO}

Alma Velia Ayala-Garay'; Eduardo Espitia-Rangel'; J. Reyes Altamirano-Cárdenas ${ }^{2}$; Arely del Rocío Ireta-Paredes'; Lucina González-Molinal; Erica Muñiz-Reyes'; Gustavo Almaguer-Vargas²*

\begin{abstract}
$\Lambda$ maranth (Amaranthus spp) has a wide range of uses as food for human consumption; this crop is characterized by its high protein content and biological value. The objective of the research was to identify which factors favor the consumption of amaranth in Xochimilco, Mexico City, by means of an opinion poll to potential consumers. The information was collected through non-probability convenience sampling, according to the criteria of selecting individuals with the willingness to be surveyed. A survey was applied to 135 people from September to December 2015. A Pearson correlation matrix was obtained through SAS version 9.3. Results indicate that $47 \%$ consume amaranth as candy, $98 \%$ mention that its flavor is ordinary. Consumption is not favored by knowing it is a functional food, only $35 \%$ know about its properties. Income level influences the frequency and quantity consumed. People, who study, or work are a niche market, they are willing to consume it for breakfast or as a snack. A transversal strategy, that encourages consumption in Mexico is required, emphasizing that amaranth is a functional food.
\end{abstract}

KEYWORS: Preferences in consumption, consumers, functional food, Amaranthus spp.

\footnotetext{
'Instituto Nacional de Investigaciones Forestales, Agrícolas y Pecuarias (INIFAP), Campo Experimental Valle de México. Carretera Los Reyes-Texcoco km 13.5, Coatlinchán, Texcoco Estado de México. C. P. 56250.

${ }^{2}$ Universidad Autónoma Chapingo (UACh), Centro de Investigaciones Económicas, Sociales y Tecnológicas de la Agroindustria y la Agricultura Mundial (CIESTAAM). Carretera México-Texcoco km 38.5, Chapingo, Texcoco Estado de México. C. P. 56230.

*Corresponding author: almagervargas@hotmail.com

Received: August 2, 2018 / Accepted: August 28, 2019

Please cite this article as follows (APA 6): Ayala-Garay, A. V., Espitia-Rangel, E،, Altamirano-Cárdenas, J. R., Ireta-Paredes, A. R., González-Molina, L., Muñiz-Reyes, E., Almaguer-Vargas, G. (2020). Factors favoring amaranth consumption in Mexico City: case study Xochimilco. Textual, 75, 75-99. doi: 10.5154.r.textual.2018.75.03
} 


\section{RESUMEN}

$\mathbf{E}$ amaranto (Amaranthus spp) tiene una amplia gama de usos en la alimentación humana; se caracteriza por su alto contenido de proteínas y la calidad biológica. El objetivo de la investigación fue identificar qué factores favorecen el consumo de amaranto en Xochimilco, Ciudad de México, mediante un sondeo de opinión a consumidores. La información se obtuvo a través de un muestreo no probabilístico por conveniencia, con el criterio de selección de individuos con disposición de ser encuestados. Se aplicó una encuesta a 135 personas de septiembre a diciembre de 2015. Se obtuvo una matriz de correlación de Pearson mediante SAS versión 9.3. Por los resultados se conoce que el $47 \%$ lo consume como golosina, 98 \% mencionan que su sabor es regular. El conocimiento sobre que es un alimento funcional no es un factor que favorece el consumo, solo un $35 \%$ sabe sobre sus propiedades. El nivel de ingreso es un elemento que favorece la frecuencia y cantidad de consumo. Las personas que estudian o trabajan son un nicho de mercado, están dispuestos a consumirlo en el desayuno o como snack. Se concluye, que se requiere una estrategia transversal que fomente el consumo, destacando que es un alimento funcional

PALABRAS CLAVE: Preferencias en el consumo, consumidores, alimento funcional, Amaranthus spp.

\section{INTRODUCTION}

Cultivating amaranth (Amaranthus spp.) has a wide range of uses as human food due to the high content and biological value of its proteins, so it can be postulated as a potential crop to alleviate food problems and malnutrition.

Escalante (2011), mentions that amaranth has similar uses to maize ranging from artisanal candy, granola, whole flour, extruded food products (fried snacks), baked goods, pasta, to even more sophisticated products such as edible oil, baby food, protein concentrates, energy bars and special nutraceutical food for diabetes or cancer patients.

Cookies and bread containing amaranth flour are hypoallergenic for those with

\section{INTRODUCCIÓN}

El cultivo de amaranto (Amaranthus spp) tiene una amplia gama de usos en la alimentación humana, debido a su alto contenido y calidad biológica de proteínas, por lo que puede ser postulado como un cultivo potencial para aliviar problemas alimentarios y de desnutrición.

Escalante (2011), menciona que el amaranto tiene una serie de usos análogos al de los cultivos básicos, como el maíz, que van desde dulces artesanales, granola, harinas integrales, alimentos extruidos (frituras), panificados, pastas, hasta productos más sofisticados, como aceites comestibles, papillas para bebés, concentrados proteicos, barras energéticas y alimentos nutracéuticos especiales para enfermos diabéticos o con cáncer. 
gluten intolerance and cannot consume baked goods made with wheat flour. According to Tennina (2014) the grain contains approximately $16 \%$ protein, this percentage is higher than in traditional cereals such as maize, rice and wheat with 9.3, 8.8, and $14.8 \%$ respectively. However, its importance does not lie in quantity but in its amino acid balance; additionally, the digestibility of its grain is $93 \%$. When amaranth and maize flours are mixed, the combination is excellent, reaching values near $100 \%$, because amino acid deficiency in one flour is high in the other.

On the other hand, Jacobsen, Iteno and Mujica (2002) mention that amaranth has high levels of lysine, methionine and cysteine, with leucine as its limiting amino acid. Protein and lipid content is higher in amaranth than in wheat, which normally has $10-14 \%$ protein and $2 \%$ lipids. In oatmeal and maize, the lipid content is approximately $6 \%$ (Repo-Carrasco, Espinoza, \& Jacobsen, 2001).

Amaranth has a protein content that goes from 13-18 \% on a dry basis and presents a good amino acid balance with high levels of lysine and adequate levels of tryptophans and sulphur-containing amino acids. Its protein quality is similar to casein and it is the highest among known vegetable proteins. Its consumption is related to a decrease of osteoporosis and "bad" cholesterol levels; it is an antioxidant for tocopherol and it helps to decrease digestive disorders and tiredness, it is recommended for lactating women (Paredes \& Valverde, 2006, Morales, Vázquez, \& Bressant, 2009). Inhibiting
Las galletas y panes adicionados con harina de amaranto son un alimento hipoalergénico para los que padecen intolerancia al gluten, y no pueden consumir panificados a base de harina de trigo. Según Tennina (2014) el grano posee aproximadamente $16 \%$ de proteína, este porcentaje es más alto que el de cereales tradicionales como el maíz, arroz y trigo con $9.3,8.8$ y $14.8 \%$ respectivamente. Sin embargo, su importancia no radica en la cantidad, sino en el balance de aminoácidos que contiene, además, la digestibilidad de su grano es de $93 \%$. Cuando se realizan mezclas de harina de amaranto con harina de maíz, la combinación resulta excelente, llegando a índices cercanos a $100 \%$, porque el aminoácido que es deficiente en uno abunda en el otro.

Por otro lado, Jacobsen, Iteno, y Mujica (2002) señalan que el amaranto tiene un nivel alto de lisina, metionina y cisteína, con leucina como el aminoácido limitante. El contenido de proteínas y lípidos es mayor en amaranto que en trigo, que normalmente contiene $10-14 \%$ de proteínas y $2 \%$ de lípidos. En la avena y el maíz el contenido de lípidos es aproximadamente 6 \% (RepoCarrasco, Espinoza, \& Jacobsen, 2001).

El amaranto tiene un contenido de proteína que va del 13-18 \% en base seca y presenta un buen balance de aminoácidos con altos niveles de lisina y adecuados valores de triptófano y aminoácidos azufrados. Su calidad proteínica es comparable con la caseína y es el más alto entre las proteínas vegetales conocidas. $\mathrm{Su}$ consumo se ha asociado con la disminución de osteoporosis y colesterol 
properties for cancer cell growth have also been attributed to amaranth because it is a source of bioactive peptides and a series of phytochemical compounds with beneficial properties for human health and with biotechnological development potential (Huerta-Ocampo, MaldonadoCervantes, \& Barba, 2012). The foregoing information makes it an ideal product for human consumption (Escobedo-López, Ayala, \& Campos, 2012), highlighting its properties as a highly nutritious food, nutraceutical and as a source for bioactive substances with clinical relevance (Algara-Suárez, Gallegos-Martínez, \& Reyes-Hernández, 2013).

Current success of the food industry depends on the capacity of adaptation and innovation of quality products that will satisfy the consumers expectations and social needs. The functional benefits of food on health is ancient, mainly throughout the history of Oriental culture where foods and medicine are considered of equally importance on preventing and healing diseases (Córtes, Chiralt, \& Puente, 2005). The concept of functional food was used for the first time in Japan in 1984, they studied the relation between nutrition, sensorial satisfaction, nutrition and modulation of physiological systems (Siró, Kápolna, Kápolna, \& Lugasi, (2008), Cortés et al.,2005). Food can be considered functional if it satisfactorily proves that it affects one or more specific body function beyond its intrinsic nutritional effects, therefore suitable to improve the state of health and wellbeing, reduce risk of illness or both (Ashwell, 2002). A functional food is also the one that helps body organs dañino; tiene poder antioxidante por el tocoferol y ayuda a disminuir trastornos digestivos y cansancio, se recomienda a mujeres en lactancia (Paredes \& Valverde, 2006, Morales, Vázquez, \& Bressant, 2009). Al amaranto también se le han atribuido propiedades inhibitorias de la proliferación celular cancerosa, ya que es una fuente de péptidos bioactivos y una serie de compuestos fitoquímicos con propiedades benéficas para la salud humana y con potencial de desarrollo biotecnológico (Huerta-Ocampo, Maldonado-Cervantes, \& Barba, 2012). Por todo lo anterior, lo hace un producto ideal para el consumo humano (Escobedo-López, Ayala, \& Campos, 2012), destacando sus propiedades como alimento altamente nutritivo, nutracéutico y como fuente de sustancias bioactivas de relevancia clínica (Algara-Suárez, GallegosMartínez, \& Reyes-Hernández, 2013).

El éxito actual de la industria alimentaria depende de la capacidad de adaptación e innovación de productos de calidad, que satisfagan las expectativas y las necesidades sociales de los consumidores. El poder funcional de los alimentos sobre la salud es de origen milenario, principalmente a lo largo de la historia de la cultura oriental, donde los alimentos y la medicina son considerados igualmente importantes en la prevención y curación de enfermedades (Cortés, Chiralt, \& Puente, 2005). El concepto de alimento funcional fue usado por primera vez en Japón en la década de 1980 y propuesto por científicos japoneses en 1984, quienes estudiaron la relación entre la nutrición, la satisfacción sensorial, la nutrición y modulación de sistemas fisiológicos 
function better and without deficiencies (Brambila, 2011). Beneficial effects can be, maintenance and promotion of a healthy state or of wellbeing and reducing the risk of suffering a pathological process or a disease (Rocandio \& Arroyo, 2000).

The main trends for future development of functional foods are related to the following facts: 1 ) changes on consumer expectations and attitudes, 2) knowledge about diet-physiological process relation and 3) changes on regulation policies (Cortés et al., 2005)

At a domestic level, amaranth production has increased from 2007 to 2016 at an average annual growth rate (AAGR) of $6.7 \%$, this means that it went from $3392 \mathrm{t}$ in 2007 to $6052 \mathrm{t}$ in 2016 (SIAP, 2017).

It is worth mentioning that in 2015 production was nearly 9 thousand tons, production mainly increased because in 2014 the price paid to the producer in terms of wages increased, reaching a maximum of $\$ 34.00$ per $\mathrm{kg}$, a minimum of $\$ 18.00$ and an average of $\$ 26.00$. This generated an excess supply for 2015, however, the price paid for that year was $\$ 18.00$ at the beginning and $\$ 12.00$ at the end, so production decreased again in 2016 and in 2017 it reached 5 thousand tons (SIAP, 2015, 2016, 2018).

Regarding consumption, despite the increasing interest on amaranth, it has not grown as expected; per capita consumption reported by SIAP was of $100 \mathrm{~g}$ in 2014, $7 \mathrm{~g}$ in 2015 and only $4 \mathrm{~g}$
(Siró, Kápolna, Kápolna, \& Lugasi, (2008), Cortés et al., 2005). Un alimento puede considerarse funcional si se demuestra satisfactoriamente que afecta a una o más funciones corporales específicas, más allá de sus efectos nutritivos intrínsecos, de modo que resulte apropiado para mejorar el estado de salud y bienestar, reducir el riesgo de enfermedad, o ambas cosas (Ashwell, 2002). También es un alimento funcional el que ayuda a que los órganos del cuerpo funcionen mejor y sin deficiencias (Brambila, 2011). Los efectos benéficos pueden ser, el mantenimiento o promoción de un estado de bienestar o salud y la reducción del riesgo de un proceso patológico o una enfermedad (Rocandio \& Arroyo, 2000).

Las principales tendencias para el desarrollo futuro de los alimentos funcionales están relacionadas con los siguientes hechos: 1) los cambios en las expectativas y las actitudes de los consumidores, 2) el conocimiento sobre la relación dieta-procesos fisiológicos y 3) los cambios en las políticas reglamentarias (Cortés et al., 2005).

A nivel nacional, la producción de amaranto se ha incrementado de 2007 a 2016 a una tasa de crecimiento medio anual (TCMA) de $6.7 \%$ lo que significa que, de 3392 t en 2007, pasó a 6052 t en 2016 (SIAP, 2017).

Cabe mencionar, que en 2015 la producción fue de casi 9 mil t, el aumento en la producción se debió principalmente a que en 2014 el precio pagado al productor en términos nominales incrementó, 
in 2017 (SIAP, 2015, 2016, 2018). Low per capita consumption in addition to excess supply during 2014-2015, contributed to a reduction in price, hence a fall in production (SIAP, 2017).

SIAP's (2017) information shows that amaranth is grown in three municipalities: Xochimilco, Tláhuac and Milpa Alta; Xochimilco stands out with an average of 86 ha during 2014-2016 (SIAP, 2017). This represents on average $57 \%$ of the harvested area in Mexico City and places Xochimilco as the main producer in the entity. Since it is the municipality that contributes the most to the production in Mexico City, it was selected to do research on factors that favor amaranth consumption. Despite being a product with nutritional and functional characteristics in human nutrition, its per capita consumption is only of a few grams annually.

Due to the aforementioned information, the objective of this research was to identify which factors favor amaranth consumption in Xochimilco through an opinion poll to potential consumers. The hypothesis shows that amaranth consumption depends on consumers knowledge because this is a functional food that contributes to the improvement of wellbeing, as well as its price.

\section{MATERIALS AND METHODS}

To analyze growth dynamics in production, methodology by FAO (Gómez, 1994) was used, it quantifies explanatory factors of agricultural production growth for a crop by calculating the Average logrando un máximo de $\$ 34.00$ por kg, un mínimo de $\$ 18.00$ y un promedio de $\$ 26.00$. Lo anterior generó un exceso en la oferta para 2015, sin embargo, el precio pagado para ese año fue de $\$ 18.00$ en un inicio y de $\$ 12.00$ al término. Por lo anterior, la producción volvió a disminuir en 2016 y en 2017 que llegó hasta 5 mil t (SIAP, 2015, 2016, 2018).

En relación con el consumo, a pesar de que hay un aumento en el interés por el amaranto, este no ha crecido como se esperaba, el consumo per cápita que SIAP reporta fue de $100 \mathrm{~g}$ en 2014, $7 \mathrm{~g}$ en 2015 y solo $4 \mathrm{~g}$ en 2017 (SIAP, 2015, 2016, 2018). El bajo consumo per cápita, aunado a que hubo un exceso de oferta durante 20142015, contribuyeron a la disminución en el precio y, por ende, una caída en la producción (SIAP, 2017).

Por información del SIAP (2017), se sabe que el cultivo del amaranto se realiza en tres alcaldías: Xochimilco, Tláhuac y Milpa Alta, sobresaliendo Xochimilco con un promedio de 86 ha durante 20142016 (SIAP, 2017). Lo que representa en promedio el $57 \%$ de la superficie cosechada en la Ciudad de México, y coloca a Xochimilco como principal productor de amaranto en la entidad. Al ser la alcaldía con mayor aporte a la producción en la Ciudad de México, se eligió para realizar la investigación sobre factores que favorecen el consumo de amaranto. A pesar de ser un producto con características nutricionales $\mathrm{y}$ funcionales en la alimentación humana, su consumo per cápita en México es de solo unos gramos de forma anual. 
Annual Growth Rate (AAGR). According to this methodology, area, yield and the interaction of both variables (combined effect), are the effects that explain growth in production.

Explanatory factors in amaranth production were calculated for the period 2003-2016 and triennial averages were used at the initial and final periods of the variables.

The area effect (A.E.) is expressed as the AAGR of the production that could have been obtained at year $n$ (year of study) if only the area varied. To calculate it, yield and prices are kept constant.

A. $E .=\left\{\llbracket\left(\frac{\operatorname{Si}(j) * \operatorname{Ri}(0) * \operatorname{Pi}(0)}{\operatorname{Si}(0) * \operatorname{Ri}(0) * \operatorname{Pi}(0)}\right)^{\frac{1}{n-1}} \rrbracket-1\right\} * 100$

Yield effect (Y.E.) takes as a variable yield per hectare. It is given by the AAGR of production that could have been obtained if only yields vary.

Y. E. $=\left\{\llbracket\left(\frac{\operatorname{Si}(0) * \operatorname{Ri}(j) * \operatorname{Pi}(0)}{\operatorname{Si}(0) * \operatorname{Ri}(0) * \operatorname{Pi}(0)}\right)^{\frac{1}{n-1}} \rrbracket-1\right\} * 100$

For both effects: A.E. = Area effect, $A_{i}(j)$ $=$ Area of the study year, $\mathrm{Y}_{\mathrm{i}(0)}=$ Yield of the base year, $\mathrm{P}_{\mathrm{i}(\mathrm{O})}=$ Price of the base year, $\mathrm{S}_{\mathrm{i}(0)}=$ Area of the base year, $\mathrm{n}=$ number of study years, Y.E. $=$ Yield effect, $Y i(j)=$ Yield of the study year.

The combined effect (C.E.) is the outcome of the interaction of yield effect and area effect (C.E. = A.E. $*$ Y.E.) and it represents what cannot be explained by yield and area growth rates.
Por todo lo anterior, el objetivo de la investigación fue identificar qué factores favorecen el consumo de amaranto en Xochimilco, mediante un sondeo de opinión a consumidores potenciales. La hipótesis de estudio refleja que el consumo de amaranto depende del conocimiento del consumidor, ya que este es un alimento funcional que contribuye a mejorar su bienestar, así como su precio.

\section{MATERIALES Y MÉTODOS}

Para analizar la dinámica de crecimiento de la producción, se utilizó la metodología de FAO (Gómez, 1994) que cuantifica los factores explicativos del crecimiento de la producción agrícola para un cultivo, a través del cálculo de su Tasa Media de Crecimiento Anual (TMCA). De acuerdo con esta metodología, los efectos que explican el crecimiento de la producción son la superficie, el rendimiento y la interacción de ambas variables (efecto combinado).

Los factores explicativos de la producción de amaranto se calcularon para el periodo 2003-2016 y se utilizaron promedios trienales en los periodos inicial y final de las variables.

El efecto superficie(E.S.) se expresa como la TMCA de la producción que se habría obtenido en el año n (año de estudio) si solo hubiera variado la superficie. Para su cálculo se mantienen constantes tanto los rendimientos como los precios.

E. S. $=\left\{\llbracket\left(\frac{\mathrm{Si}(\mathrm{j}) * \operatorname{Ri}(0) * \mathrm{Pi}(0)}{\mathrm{Si}(0) * \operatorname{Ri}(0) * \operatorname{Pi}(0)}\right)^{\frac{1}{\mathrm{n}-1}} \rrbracket-1\right\} * 100$ 
The sum of the three effects explains the AAGR of crop production, therefore:

A.E. + Y.E. + C.E. $=$ AAGR of the production.

To obtain information regarding amaranth consumers, a survey was designed with quantitative variables and economic and social categories, the structured and direct survey is used when there is not enough information about certain being researched or when the information cannot be obtained through other techniques (Rojas, 2002). The obtained data considered the following aspects: a) general characteristics of the consumer: gender, age, occupation and years of study, b) current amaranth consumption, type of consumed product, knowledge of nutritional value, consumption frequency, quantity consumed; and consumer preferences: price willing to be paid for the product, selling point, hour of consumption and form of consumption.

The information was gathered in Mexico City, in the municipality of Xochimilco, in 2015 it had a population of 415933 inhabitants (INEGI, 2015). This municipality was chosen because it is the largest producer or amaranth in México City, on average it cultivated an area of 97 hectares of this crop during 2013-2015; standing out from the municipalities of Tláhuac and Milpa Alta (SIAP, 2017). Additionally, its concentric location where public institutions and those from the private sector are joined, gives access to people with different income levels and food habits. A non-probability convenience sampling was made, using the criteria of selecting individuals willing to be
El efecto rendimiento (E.R.) toma como variable el rendimiento por hectárea. Está dado por la TMCA de la producción que se habría obtenido sí solo variaran los rendimientos.

Para ambos efectos: E.S. = Efecto superficie, $S_{i}(j)=$ Superficie del año de estudio, $\mathrm{R}_{\mathrm{i}(0)}=$ Rendimiento del año base, $\mathrm{P}_{\mathrm{i}(0)}=$ Precio del año base, $S_{i(0)}=$ Superficie del año base, $\mathrm{n}$ = número de años en estudio, E.R. = Efecto rendimiento, $\mathrm{R} i(\mathrm{j})$ = Rendimiento del año en estudio.

E. R. $=\left\{\llbracket\left(\frac{\operatorname{Si}(0) * \operatorname{Ri}(j) * \operatorname{Pi}(0)}{\operatorname{Si}(0) * \operatorname{Ri}(0) * \operatorname{Pi}(0)}\right)^{\frac{1}{n-1}} \rrbracket-1\right\} * 100$

El efecto combinado (E.C.) resulta de la interacción del efecto rendimiento y el efecto superficie (E.C. = E. S. * E. R.), y representa lo no explicado por las tasas de crecimiento de rendimiento y superficie.

La suma de los tres efectos explica la TMCA de la producción del cultivo, por tanto:

E.S. + E.R. + E. C. = TMCA de la producción.

Para obtener la información de los consumidores de amaranto se diseñó una encuesta con variables cuantitativas y categóricas de carácter económico y social, la encuesta estructurada o dirigida se emplea cuando no existe suficiente material informativo sobre ciertos aspectos que interesa investigar, o cuando la información no puede conseguirse a través de otras técnicas (Rojas, 2002). Los datos obtenidos consideraron los siguientes aspectos: a) características generales del consumidor: género, 
interviewed. A survey was applied to 135 people from September to December 2015.

Data analysis was made in Excel 2016 in a descriptive manner (an analysis was made for each variable, the aim was to define, classify and characterize the factors that favor amaranth consumption). A Pearson correlation matrix was obtained with a statistical software, SAS 9.3, the variables were correlated and associations of interest were obtained.

Interpretation of Pearson's rho coefficient: values close to 1 indicate a strong and positive correlation. Values close to -1 indicate a strong and negative correlation. Values close to 0 indicate non-linear correlation. There might be another type of correlation, but it is not linear. Positive or negative signs only indicate the direction of the relation; a negative sign indicates that a variable increases while the other one decreases or vice versa, and a positive sign, that a variable increases while the other one also increases or decreases, if the other one does so (Martínez, Tuya, Martínez, Pérez, \& Canovas, 2009). Pearson's correlation coefficient was used because it measures the extent to which the same individuals occupy a relative position with regard to two variables which in this analysis correspond to an interval scale.

\section{RESULTS}

\section{AMARANTH PRODUCTION IN MEXICO}

Amaranth in Mexico was cultivated in 12 states from 2007 to 2016, Puebla edad, ocupación y años estudiados; b) consumo de amaranto actual, tipo de producto consumido, conocimiento del valor nutricional, frecuencia de consumo, cantidad consumida; y c) preferencias del consumidor: precio dispuesto a pagar por el producto, punto de venta, hora de consumo y forma de consumo.

El levantamiento de la información se realizó en la Ciudad de México, en la Alcaldía de Xochimilco, que para 2015 contaba con una población de 415933 habitantes (INEGI, 2015). Se eligió dicha Alcaldía por ser el máximo productor de amaranto de la Ciudad de México, ya que, en promedio, durante el 2013-2015 destinó a la superficie sembrada 97 hectáreas para su cultivo, destacando sobre las Alcaldías Tláhuac y Milpa Alta (SIAP, 2017). Además, su ubicación concéntrica donde confluyen instituciones tanto del sector público como privado permite tener acceso a personas con diferentes niveles de ingresos y, por ende, de hábitos alimenticios. Se realizó un muestreo no probabilístico por conveniencia, con el criterio de selección de individuos que tuvieran la disposición de ser encuestados. Se aplicó una encuesta a 135 personas durante los meses de septiembre a diciembre del 2015.

El análisis de datos se realizó con el software Excel 2016 de forma descriptiva (en cada variable se hizo un análisis donde la finalidad fue definir, clasificar y caracterizar los factores que favorecen el consumo del amaranto). También se obtuvo una matriz de correlación de Pearson mediante el software estadístico, 
and Tlaxcala followed by the State of Mexico and Morelos stand out because of their harvested area and production. The highest average yields are $2.11 \mathrm{t} \mathrm{ha}^{-1}$ in the State of Mexico and $1.31 \mathrm{t} \mathrm{ha}^{-1}$ in Morelos (SIAP, 2017). Other entities where amaranth cultivation is reported are México City, Oaxaca, Hidalgo, San Luis Potosi, Guanajuato, Queretaro, Jalisco and Durango (SIAP, 2017).

During 2007-2016, amaranth production was concentrated in the states at the center of the Mexican Republic, Tlaxcala, Puebla, State of Mexico and Morelos, which have maintained an average production of 1 398, 2 486, 503 and 304 t respectively (SIAP, 2017).

\section{AMARANTH PRODUCTION DYNAMICS}

The results from the analysis of growth dynamics in production (Table 1) between the years 2003 and 2016 show that at a domestic level, the annual average growth rate was of $11.93 \%$, growth basically explained by a $12.62 \%$ annual average increase in the area and without an increase on yield, this variable has decreased at an annual average rate of $0.62 \%$.

The State of Tlaxcala excelled in the period of time under study, it is the main domestic producer in recent years, the area in this state has increased at a 33.86 $\%$ average annual rate and yields at an average of $4.47 \%$ a year.

It can be said that there is little innovation that can allow increase in yields per state, however, as it was observed between 2015
SAS versión 9.3, se correlacionaron las variables, de las cuales se identificaron asociaciones de interés.

La interpretación del coeficiente rho de Pearson: valores próximos a 1, indican una correlación fuerte y positiva. Valores próximos a -1 indican una correlación fuerte y negativa. Valores próximos a cero indican que no hay correlación lineal. Puede que exista otro tipo de correlación, pero no lineal. Los signos positivos o negativos solo indican la dirección de la relación; un signo negativo indica que una variable aumenta a medida que la otra disminuye o viceversa, y uno positivo que una variable aumenta conforme la otra también lo haga, disminuye si la otra también lo hace (Martínez, Tuya, Martínez, Pérez, \& Canovas, 2009). Se utilizó el coeficiente de correlación de Pearson, pues es una medida del grado en que los mismos sujetos ocupan una posición relativa respecto a dos variables que, en este análisis, corresponden a una escala de intervalos.

\section{RESULTADOS}

\section{PRODUCCIÓN DE AMARANTO EN MÉXICO}

El cultivo del amaranto en México de 2007 a 2016 se realizó en 12 estados de los cuales sobresalen por su superficie cosechada y producción, Puebla y Tlaxcala, seguidos por el Estado de México y Morelos. Los mayores rendimientos promedio son de $2.11 \mathrm{t} \cdot \mathrm{ha}^{-1}$ en el Estado de México y con $1.31 \mathrm{t} \cdot \mathrm{ha}^{-1}$ para Morelos (SIAP, 2017). Otras entidades donde se reporta su cultivo es la Ciudad de México, Oaxaca, Hidalgo, San 
Table 1. Explanatory factors of growth in amaranth production during 2003-2016.

Cuadro 1. Factores explicativos del crecimiento de la producción de amaranto en el periodo 2003-2016.

\begin{tabular}{lcccc}
\hline \multirow{2}{*}{$\begin{array}{c}\text { Federal Entity/ } \\
\text { Entidad Federativa }\end{array}$} & $\begin{array}{c}\text { AAGR (\%)/ } \\
\text { TMCA (\%) }\end{array}$ & Area/Superficie & Yield / Rendimiento & $\begin{array}{c}\text { Combined / } \\
\text { Combinado }\end{array}$ \\
\cline { 3 - 5 } Puebla & 1.43 & 6.44 & -4.71 & -0.30 \\
Tlaxcala & 39.85 & 33.86 & 4.47 & 1.51 \\
Estado de México & 16.86 & 15.99 & 0.75 & 0.12 \\
Ciudad de México & -0.06 & -0.14 & 0.07 & 0.00 \\
Domestic/Nacional & 11.93 & 12.62 & -0.62 & -0.08 \\
\hline
\end{tabular}

Source: Compiled by the author with information from SIAP, 2017 and Gómez, 1994.

Fuente: Elaboración propia con información de SIAP, 2017 y Gómez, 1994.

and 2016, increase in yield reflects on the decrease in price.

It is necessary to develop the market's potential in order to a allow possible increase in production without affecting with low prices and thereby a decrease of cultivated area.

\section{GENERAL CHARACTERISTICS OF THE CONSUMER}

From the surveys applied in the municipality of Xochimilco, the following information about consumption was obtained. Age range varied from 16 to 70 years old. The highest percentage was concentrated in the category from 21 to 50 years old with $58 \%$.

The respondents' occupation was, $38 \%$ employed, $34 \%$ students, $16 \%$ house wives and $12 \%$ were entrepreneurs, retired people and those who did not mention their profession.
Luis Potosí, Guanajuato, Querétaro, Jalisco y Durango (SIAP, 2017).

Durante 2007-2016, la producción de amaranto se concentró en estados del centro de la República Mexicana, Tlaxcala, Puebla, Estado de México, y Morelos, que han mantenido una producción promedio de 1398, 2 486, 503, y 304 t, respectivamente (SIAP, 2017).

\section{DINÁMICA DE LA PRODUCCIÓN DE AMARANTO}

Los resultados del análisis de la dinámica del crecimiento en la producción (Cuadro 1) entre los años 2003 y 2016 muestran que, a nivel nacional, la tasa de crecimiento media anual fue de $11.93 \%$ crecimiento explicado básicamente por el incremento de $12.62 \%$ promedio anual en la superficie $\mathrm{y}$ sin aumento en rendimiento, variable que ha decrecido a una tasa media anual de $0.62 \%$. 
Regarding schooling data, $50 \%$ of the respondents had 10 to 17 years of schooling, $38 \%$ from 1 to 9 and $12 \%$ from 18 to 23 years of schooling. Regarding their income, 50 \% receives between $\$ 1001.00$ and \$5 000.0 (Figure 1)

Figure 1. Respondents income range.

Figura 1. Rango de ingreso de los encuestados.

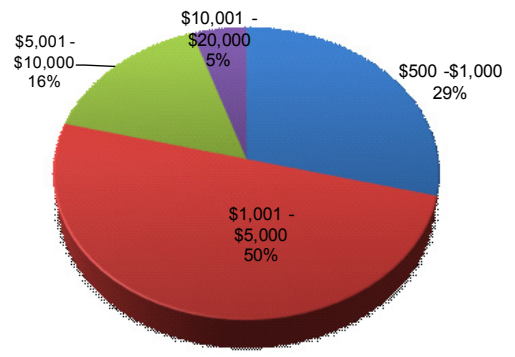

\section{CURRENT AMARANTH CONSUMPTION}

Ninety-seven percent of the respondents have tasted amaranth, $3 \%$ have not. Forty two percent have tasted it in food products, whether in cereals, vegetables, milk or flour (Figure 2), the rest has used it in non-food products (cosmetics). It is currently known that there are many ways to consume amaranth, the products that contain popped grains and flour complement the mixture to elaborate candy, pound cakes and multigrain products that promote good health, they can also be a part of dishes prepared with the leaves as a type of vegetable. This crops has been incorporated to several industrialized foods, such as: baking goods (bread, cakes and cookies), extruded food products (cereal flakes, tortillas and pasta). It is mainly consumed as popped grain from which the following
Destaca en el periodo analizado el estado de Tlaxcala que se ha posicionado como el principal productor nacional en los últimos años, la superficie en este estado se ha incrementado a una tasa media anual de $33.86 \%$ y rendimientos del $4.47 \%$ promedio anual.

Se puede decir que hay poca innovación que permita aumentar los rendimientos por estado, no obstante, como se observó entre los años 2015 y 2016 los incrementos en la producción se reflejan en caídas de precio.

Es necesario desarrollar el potencial de mercado con el fin de dar salida a los posibles incrementos de producción, sin afectar con bajos precios y, por ende, la reducción de superficie destinada a su siembra.

\section{CARACTERÍSTICAS GENERALES DEL CONSUMIDOR}

Figure 2. Different amaranth food applications.

Figura 2. Presentación en cómo se consume el amaranto.

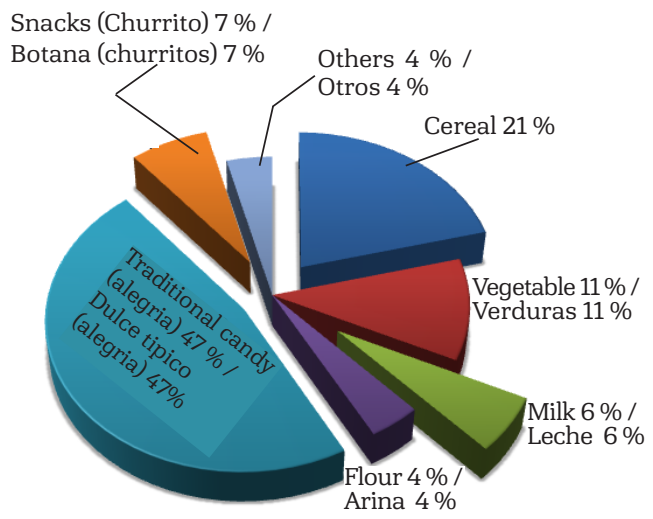

86 Economics and public policies 
products are elaborated: alegrias, cereal, granola, atole, pinole, marzipan, etc. There are also fried snacks, amaranth flour used in dishes such as soups (grain and flour), breakfast cereal (whole, popped or sprouts and ground) (Escobedo-López et al., 2012) (Figure 2). Barrón-Yañez (2009) found that amaranth sprouts have good flavor and contain concentration levels of saponins bellow toxic levels and these can function as phytochemicals to strengthen the immunological system.

In addition, $98 \%$ consider that amaranth is ordinary in flavor and only $2 \%$ consider it to be bad. Regarding the nutritional properties of amaranth, $35 \%$ of the respondents know the nutritional properties of the product, in spite of the grain's high-protein content which fluctuates from 14 to $17 \%$ (Alejandre, Valdés, \& García, 2012). Additionally, its digestibility is very high, reaching between 80 and $92 \%$. Amaranth can provide food throughout the whole crop cycle because it produces a large amount of leaves which are rich in vitamins, proteins and minerals, among which iron, calcium and phosphorus excel.

Amaranth leaves have more iron than those of spinach, this makes it ideal to prevent anemia which mainly affects pregnant women and children. Besides eating it fresh, the leaf can be dehydrated and grinded to be preserved as powder. After being harvested, the grain can be used as cereal, toasted and ground to make flour and many other products (Escobedo-López et al., 2012). The use of amaranth as a source of energy and
De las encuestas aplicadas en la Alcaldía Xochimilco, se obtuvo la siguiente información sobre el consumo.

De los encuestados, el $43 \%$ fueron hombres y el $57 \%$ mujeres. El rango de edad varió desde 16 a 70 años. El mayor porcentaje se concentró en la categoría de 21 a 50 años con $58 \%$.

La ocupación de los encuestados fue $38 \%$ empleados, $34 \%$ estudiantes, $16 \%$ amas de casa y en el $12 \%$ quedaron empresarios, jubilados y los que no indicaron su profesión.

En datos de escolaridad, el $50 \%$ de los encuestados tiene de 10 a 17 años de estudios, el $38 \%$ de 1 a 9 años, y un $12 \%$ de 18 a 23 años de escolaridad. Sobre su ingreso, el $50 \%$ recibe entre $\$ 1001.00$ y $\$ 5000.00$ (Figura 1).

\section{CONSUMO ACTUAL DE AMARANTO}

El $97 \%$ de los encuestados ha probado el amaranto, el $3 \%$ no lo ha hecho. Señala un $42 \%$ que lo ha consumido en productos alimenticios, ya sea en cereal, verdura, leche o harina (Figura 2), el resto lo ha utilizado en productos no alimenticios (cosméticos). Actualmente, se sabe que existen diferentes formas de consumir el amaranto, los productos que contienen grano reventado y harina son los que complementan la mezcla para elaborar dulces, panques y multigranos que promueven la salud, además pueden formar parte de platillos preparados con las hojas en forma de verdura. El cultivo se ha integrado en varios alimentos industrializados como: 
protein is a sustainable proposal at a regional level, so its use to prepare a hot beverage such as atole, is an option of proper nutritional quality, bioavailability and highly accepted by older adults (González, Reyes, Gaytán, Campos, \& Palos, 2018).

Additionally, $50 \%$ of the respondents consume amaranth every three days or at least once a week. While the other 50 $\%$ consumes it once a week or a month. It has been noticed in other research that even in the locations where amaranth is produced, it is not consumed by the producers, even though they mention that consumption has been carried out for generations. In Temoac Morelos, 22 $\%$ of the producers under study do not consume amaranth or sporadically do so (once a month) as in the Central Region of Mexico (Ayala, Espitia, Rivas, Almaguer, \& Preciado, 2016a).

It is important to promote amaranth consumption, in addition to trying to incorporate it to the populations general diet with the purpose of using its nutritional richness. Several authors mention that in recent years there has been a great interest in the consumption of this grain, at a domestic level as much as at an international level due to its nutritional properties (Paredes, 1994, Alejandre et al., 2012, \& Escobedo-López et al., 2012). Sánchez and Navarrete (2018), mention that the expansion, diversification and modernization of amaranth products (flour, bread, cookies, granola, snacks, among others) help increase domestic consumption. In productos de repostería (panes, pasteles y galletas), productos de extrusión (hojuelas de cereal, tortillas y pastas). Se consume principalmente como grano reventado del cual se elaboran los siguientes productos finales: alegrías, cereal, granolas, atoles, pinole, mazapán, etc. También existen frituras, harina de amaranto que se emplea en platillos como sopas (grano y harina), cereal para el desayuno (entero, reventado o germinado y molido) (Escobedo-López et al., 2012) (Figura 2). Barrón-Yañez (2009) encontró que el germinado de amaranto presenta buen sabor y contiene una concentración inferior a los niveles tóxicos de saponinas y estas pueden contribuir como fitoquímicos para reforzar el sistema inmunológico.

Asimismo, el $98 \%$ considera que el sabor del amaranto es regular y solo $2 \%$ lo considera malo. Sobre las propiedades nutricionales del amaranto, un $35 \%$ de los encuestados declaró que sí conoce las propiedades nutricionales del producto, a pesar de la riqueza proteínica del grano que fluctúa de 14 a $17 \%$ (Alejandre, Valdés, \& García, 2012). Además, su digestibilidad es muy alta, alcanzando entre el 80 y el 92 \%. El amaranto puede aportar alimento a lo largo del ciclo de cultivo por su abundante producción de hojas, que son ricas en vitaminas, proteínas y minerales, entre los que destaca el hierro, el calcio y el fósforo.

La hoja de amaranto tiene más hierro que la espinaca, lo que la hace ideal para evitar la anemia que afecta principalmente a mujeres embarazadas y a niños. Además de consumirse fresca, la hoja puede deshidratarse y molerse para conservarla 
Mexico, this food is not considered as staple food (Ayala et al., 2012) despite there being a relevant market potential as a nutritional and functional food. It was until 2019 that amaranth was included in the basic food basket in two modalities: as amaranth based products and as snacks (DOF, 2019). The respondents report that $64 \%$ of them eat up to 50 grams a week and the other $36 \%$ more than 50 grams.

Gonzalez et al., 2018 conclude that the appropriate amount of proteins and essential amino acids in the diet is important to gain muscle mass, so amaranth consumption in the diet of older adults shows an encouraging picture towards fighting sarcopenia which is characterized by its effect on the muscular degenerative process and it is part of the fragility process.

\section{CONSUMPTION PREFERENCES}

Fourty-four percent of the respondants mention that at the moment of buying a product made with amaranth, they take into consideration its flavor (Figure 3) and $34 \%$ the quality of the product. This seems to be closely related to the availability of the product in the market, because the products are elaborated with artisanal methods, specifically alegria, which is the most consumed product by the respondents ( $47 \%$ ) and it is obtained with street vendors at low prices so ocassionally, flavor and quality are not good (Escalante, 2011). Even though the existence of regulation NMX-116SCFI-2010 "Agricultural products destined for human use and consumption-popped en forma de polvo. Después de la cosecha, el grano puede emplearse como cereal, tostado y molido para hacer harina y gran cantidad de derivados (Escobedo-López et al., 2012). La utilización del amaranto como fuente de energía y proteína resulta en una propuesta sustentable regional, por lo que la utilización en una bebida caliente típica como el atole es una opción de adecuada calidad nutricional, biodisponible y muy aceptable en las personas adultas mayores (González, Reyes Gaytán,Campos, \& Palos, 2018).

También el $50 \%$ de los encuestados señala que la frecuencia de consumo del amaranto puede ser cada tercer día o al menos una vez a la semana. Mientras que el otro $50 \%$ menciona que su frecuencia de consumo es intersemanal o una vez al mes. Cabe mencionar que, en otras investigaciones, se ha detectado que aun en los lugares donde se produce amaranto, no es consumido por los productores a pesar de que ellos mencionan que el consumo se ha dado durante generaciones. En Temoac Morelos, $22 \%$ de los productores estudiados no consumen amaranto o, lo llegan a consumir de manera esporádica (una vez al mes) y de igual forma en la Región Centro de México (Ayala, Espitia, Rivas, Almaguer, \& Preciado, 2016a).

Es importante, impulsar el consumo del amaranto, además de tratar de incorporarlo a la dieta general de la población con el propósito de aprovechar su riqueza nutritiva. Diversos autores, mencionan que en años recientes ha habido un gran interés en el consumo de este grano, tanto a nivel nacional como internacional debido 
amaranthus (Amaranthus spp.) grain for human use and consumption-specifications and essay methods" (DOF, 2010), this regulation is omitted with products sold in informal commerce. Also, during the stages of threshing and putting in bags, there are risks of contamination by metals, glass and cristals, there are also chemical risks due to producers storing in small spaces near backyard pens, pesticides, diesel, because everything is stored in the same space (Ayala-Garay, Espitia-Rangel, Rivas-Valencia, Martínez-Trejo, \& AlmaguerVargas, 2016b).

To comply the regulation, the popped amaranth grains must be clean at any level of quality, without any strange visible material, pests or harm caused by them that could affect the overall appearance of the product, from abnormal humidity, any abnormal smell or flavor suggesting a rancid product (Escalante, 2011). Additionally, the popped grain must cover specific physical, physiochemical, microbiological and toxicological specifications (Ayala et al., 2012).

Forty three percent of the respondents mention that they are willing to pay up to $\$ 20$. 00 for a product containing amaranth, $41 \%$ could pay between $\$ 21$ and $\$ 50$ and the remaining $16 \%$ could pay more than $\$ 51$. Sánchez and Navarrete (2018) conclude that the boom in consumption has influenced the decisions in the chain dynamics, increasing the market value of amaranth products; adapting to new demands and maintaining the traditional artisanal profile. The respondents consider that the product can be distributed from street vendors a sus propiedades nutritivas (Paredes, 1994, Alejandre et al., 2012, \& EscobedoLópez et al., 2012). Sánchez y Navarrete (2018), mencionan que la ampliación, diversificación y modernización de los productos derivados del amaranto (harinas, pan, galletas, granolas, frituras, entre otros) contribuyen a incrementar el consumo nacional. En México este alimento no se consideraba estratégico (Ayala et al., 2012), a pesar de que existe un mercado potencial relevante como alimento nutritivo y funcional. Es a partir del año 2019, que el amaranto es incluido en la canasta básica en dos modalidades: como productos a base de amaranto y como golosinas (DOF, 2019). Los encuestados reportan que un $64 \%$ de ellos consume hasta 50 gramos a la semana y un $36 \%$ restante más de 50 gramos.

González et al., 2018, concluyen que la cantidad adecuada de proteínas en la dieta y aminoácidos esenciales es primordial para aumentar la masa muscular, por lo que, el consumo de amaranto en la alimentación de adultos mayores muestra un panorama alentador al combatir la sarcopenia que se caracteriza por la incidencia en el proceso degenerativo muscular y que forma parte del proceso de fragilidad.

\section{PREFERENCIAS EN EL CONSUMO}

Igualmente el $44 \%$ de encuestados, menciona que al momento de comprar un producto elaborado a base de amaranto toma en cuenta el sabor (Figura 3) y $34 \%$ la calidad del producto. Se considera que está relacionado estrechamente con la disponibilidad de productos que 
Figure 3. Factors influencing the selection of amaranth products.

Figura 3. Factores que influyen en la elección de un producto de amaranto.

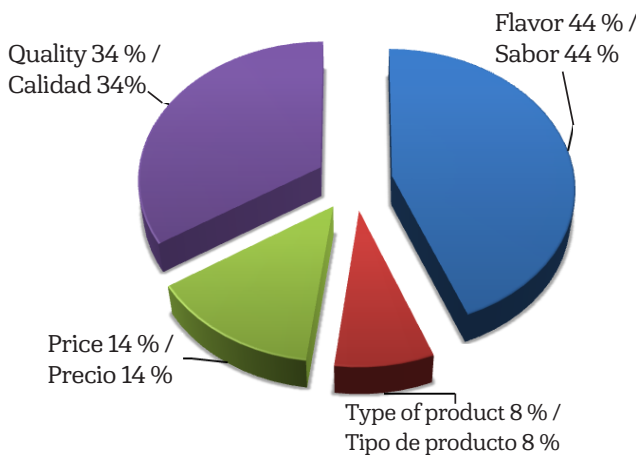

to supermarkets, as long as they comply the current quality regulation. Thirty two percent considers that local stores are the best places to commercialize this product, $26 \%$ mentions that in supermarkets, $25 \%$ street vendors, $10 \%$ street markets and $7 \%$ local markets.

Forty six percent of those who consume amaranth do so during breakfast, $19 \%$ for lunch and only $3 \%$ for dinner, finally, $32 \%$ do so between meals. Additionally $73 \%$ of consumers prefer to eat a product made with amaranth as a snack, while $22 \%$ prefer a food product and $5 \%$ prefer a nonedible product, it is considered that there is a lack of knowledge by the consumer related to different types of products elaborated with amaranth. According to Alejandre et al (2012) the grain is mainly used to elaborate artisanal candy known as alegria.

Despite snacks being the most preferred product of the respondents, $47 \%$ would existen en el mercado, ya que los artículos encontrados se elaboran con métodos artesanales, específicamente la alegría, que es el producto más consumido por los encuestados (47\%) y se obtiene en puestos ambulantes, a bajos precios por lo que el sabor y la calidad en ocasiones no son buenos (Escalante, 2011). No obstante, que existe la Norma NMX-116-SCFI-2010, "Productos agrícolas destinados para consumo humano-grano reventado de amaranto (Amaranthus spp.) para uso $\mathrm{y}$ consumo humano-especificaciones y métodos de ensayo" (DOF, 2010), dicha Norma se omite en los productos que se venden en el comercio informal. Además, durante las etapas de trilla y encostalado existen riesgos de contaminación por metales, vidrios y cristales, además de riesgos químicos por la condición de almacenaje en espacios pequeños por productores en lugares cerca de los corrales de sus animales de traspatio, insecticidas, diésel, ya que todo se almacena en el mismo espacio (AyalaGaray, Espitia-Rangel, Rivas-Valencia, Martínez-Trejo, \& Almaguer-Vargas, 2016b).

Para cumplir con la norma, los granos de amaranto reventado, en cualquiera de sus grados de calidad deben estar limpios, exentos de cualquier materia extraña visible, de plagas y daños causados por ellas, que afecten el aspecto general del producto, de humedad anormal, de cualquier olor o sabor anormal o que indiquen rancidez (Escalante, 2011). Asimismo, el grano reventado de amaranto debe cumplir con especificaciones físicas, fisicoquímicas, microbiológicas y toxicológicas (Ayala et al., 2012). 
like to eat it as a food product, $42 \%$ as snacks and $11 \%$ in presentations such as make up or creams, etc. In Mexico, even though the artisanal market remains as one of the fundamental pillars of amaranth production, the growth of the health market regarding whole grains has satisfyingly positioned amaranth enabling an increase in production in the country. There is currently a higher number of enterprises producing and transforming amaranth which have been slowly positioned in the market. Most of them have a distinctive sign that separates them from the rest and places them in the market, this has enabled the consumer to identify a great variety of products of domestic origin that maintain an accurate level of quality (EscobedoLópez et al., 2012). Sánchez and Navarrete (2018) mention that according to their production, rural agri-food industry can be classified as specialized and diversified. In the specialized part, one or two products are made prioritizing the one they elaborate the best; while, in the diversified part they develop three or more types of products, as well as their variations.

For amaranth to be consumed in Mexico, the benefits it offers to consumers must be known, besides its versatility to be used in salads, atoles, desserts, soups and the classic bar known as alegria. Several institutions have focused on contributing to a healthier nutrition creating, snacks, bars, waffles (CONACYT, 2016). There are consumption alternatives for amaranth in combination with other ingredients, this shows amaranth's versatility but most of all, the nutritional benefits for the organism. Amaranth as a functional
También el $43 \%$ de las personas que fueron encuestadas, mencionan que están dispuestos a pagar hasta \$20.00 por un producto que contenga amaranto, $41 \%$ podría pagar entre \$21 y \$50 y el restante $16 \%$ podría pagar más de \$51. Sánchez y Navarrete (2018) concluyen que el auge de consumo ha influido en las decisiones de la dinámica de la cadena, incrementando el valor comercial de los productos de amaranto; adaptándose a las nuevas exigencias y manteniendo el perfil artesanal tradicional. Los encuestados consideran que el producto puede distribuirse desde puestos ambulantes hasta supermercados, solo que cumplan con las normas de calidad vigentes. El $32 \%$ considera que en tiendas locales debería ser el mejor lugar para comercializarse, un $26 \%$ menciona que, en supermercados, $25 \%$ puestos ambulantes, $10 \%$ en tianguis y $7 \%$ en mercados locales.

Asimismo, el $46 \%$ de los que consumen amaranto lo hace durante el desayuno, $19 \%$ en la comida y solo el $3 \%$ en la cena, finalmente el $32 \%$ lo hace en otro momento distinto a la comida, cena o desayuno. Además de que el $73 \%$ de los consumidores prefieren consumir un producto elaborado a base de amaranto como golosina, mientras que un $22 \%$ prefiere un producto alimenticio $\mathrm{y}$ $5 \%$ prefiere un producto que no sea comestible, se considera que existe un desconocimiento por parte del consumidor en relación con diferentes tipos de productos que pueden ser elaborados a partir de amaranto. De acuerdo con Alejandre et al. (2012) el 
food can be a great tool to contribute on decreasing malnutrition of 24 million people with poor nutrition registered in 2016 in Mexico (CONEVAL, 2017). It can also be cultivated as a rain fed crop and it is resistant to drought, these makes it an alternative crop for production and adequate consumption in marginalized regions in Mexico (Ayala-Garay et al., 2016a).

\section{PEARSONS CORRELATIONS}

Regarding the calculated correlations, some of them help prove the assumptions of the economic theory (Table 2). All the correlations were significant at a 0.01 level with a unilateral statistical exam. The association between income level and consumption frequency was positive and high.

There was a moderate positive degree of association between amaranth grano es utilizado principalmente para la elaboración artesanal del dulce conocido como alegría.

A pesar de ser las golosinas el producto preferido de los encuestados, al $47 \%$ les gustaría consumirlo como producto alimenticio, el $42 \%$ como golosina y el $11 \%$ en presentaciones como maquillaje o cremas, etc. En México, aunque el mercado artesanal sigue siendo uno de los pilares fundamentales de la producción de amaranto, el crecimiento del mercado de la salud en cuanto a granos integrales ha permitido al amaranto posicionarse de una manera satisfactoria permitiendo un mayor impulso a la producción en el país. Actualmente ya existe un mayor número de empresas productoras $\mathrm{y}$ transformadoras de amaranto que poco a poco se han ido posicionando en el mercado. La mayoría maneja un signo distintivo que lo diferencia y coloca dentro del mercado, lo cual ha permitido al

Table 2. Pearson's correlation coefficient ${ }^{\S}$ Frequency of consumption

Cuadro 2. Coeficientes de correlación de Pearson ${ }^{\S}$

\begin{tabular}{lccc}
\hline & $\begin{array}{c}\text { Income level/ } \\
\text { Nivel de ingreso }\end{array}$ & $\begin{array}{c}\text { Price willing to be paid/ } \\
\text { Precio dispuesto a pagar }\end{array}$ & $\begin{array}{c}\text { Product presentation/ } \\
\text { Presentación del producto }\end{array}$ \\
\hline $\begin{array}{l}\text { Quantity consumed/ } \\
\text { Frecuencia de consumo } \\
\text { Quantity consumed/Cantidad que } \\
\text { consume }\end{array}$ & 0.79 & \\
$\begin{array}{l}\text { Precio dispuesto a pagar / } \\
\text { Price willing to be paid } \\
\text { Años de estudio / Years of schooling } \\
\text { Occupation/ Ocupación }\end{array}$ & 0.69 & \\
\hline
\end{tabular}

${ }^{5}$ Prob > |r| bajo HO: Rho=0, N=135. 
consumption in its different presentations in relation to occupation. Additionally, the correlation was significant at a 0,01 level with a unilateral statistical test. Income level and quantity consumed was also positive and high. The associations between income level and the price willing to be paid are positive and high, as well as, years of schooling, the price willing to be paid was positive and high. Income level has an effect on frequency and the quantity consumed. People who study or work are a market niche willing to consume it for breakfast or as a snack.

Recent research show the versatility of amaranth to obtain microcapsules or cyclodextrines from its starch content and it is relevant to the food and drug industry because vitamins, minerals and antioxidants can be introduced in them, they also maintain aromas and flavors and stabilize medicine (Arce-Vázquez, PonceAlquicira, Delgado-Fornué, Pedroza-Islas, Díaz-Godinez, \& Soriano-Santos, 2016).

\section{CONCLUSIONS}

Amaranth production in Mexico has shown dynamic growth mainly explained by the increase in cultivated area and with scarce use of innovations to increase yield per unit of area. People who study or work are an important niche market for elaborated amaranth products, they are mostly willing to consume it for breakfast or as a snack, pay prices from $\$ 20.00$ to $\$ 51.00$ and mainly being available in local stores, supermarkets and street ventures. Flavor and quality must be present in the elaboration of amaranth products, consumidor identificar una gran variedad de productos de origen nacional que mantienen un nivel de calidad adecuado (Escobedo-López et al., 2012). Sánchez y Navarrete (2018) señalan que, de acuerdo con su producción, la agroindustria rural se puede dividir en especializadas y diversificadas. En la especializada se elabora uno o dos productos, dando prioridad a lo que mejor saben hacer; mientras que, en la diversificada, desarrollan tres o más tipos de productos, así como sus variedades.

Para que se consuma el amaranto en México, es necesario se conozcan todas las bondades que ofrece al consumirse, además de lo versátil que puede ser para prepararse en ensaladas, atoles, postres, sopas, además de la clásica palanqueta como alegría. Diversas instituciones se han enfocado en contribuir a una alimentación más saludable, creando botanas, barras, waffles (CONACYT, 2016). Existen alternativas de consumo del amaranto en combinación con otros ingredientes, que muestra la versatilidad del amaranto, pero, sobre todo, los aportes nutrimentales y benéficos para el organismo. El amaranto como alimento funcional puede ser una gran herramienta para contribuir a disminuir la desnutrición de los 24 millones de personas en pobreza alimentaria que para 2016 se contabilizó en México (CONEVAL, 2017). Además de que puede cultivarse bajo temporal y es resistente a sequías, lo que lo hace una alternativa de producción y consumo adecuado para regiones marginadas de México (AyalaGaray et al., 2016a). 
even though alegria (snack) is the most consumed product, the respondents are interested in amaranth food products.

Amaranth consumption does not rely on consumers knowing it is a functional food contributing to improve their wellbeing, because only $35 \%$ of the consumers is aware of its properties. Income level does affect the frequency and quantity consumed.

The population is not aware of amaranth's nutritional diversity, this causes an integral waste of the plant since it can be used to prepare desserts, soups, salads, atoles, pound cakes and its flour can be combined with soy or maize to increase the protein level of the food.

Amaranth as it has been traditionally consumed, as a bar, is bought in an informal manner. It is sold without a label so the elaboration and the ingredients are unknown, in the formal market it would have a label and include information contained in labels according to the Mexican Regulation NMX-116-SCFI-2010 of amaranth.

An institutional transversal strategy that will encourage cultivation and consumption of amaranth in Mexico is required, highlighting the fact that as it is drought resistant for cultivation and production, it is also a functional food that apart from nurturing, it prevents certain diseases due to its high content of essential amino acids and active biopeptides.

The information regarding its nutritional properties and functions must

\section{CORRELACIONES DE PEARSON}

Sobre las correlaciones que se calcularon, se tienen algunas que permiten comprobar supuestos de la teoría económica (Cuadro 2). Todas las correlaciones fueron significativas en el nivel 0.01 con un examen estadístico unilateral. La asociación entre el nivel de ingreso y la frecuencia de consumo fue positiva y alta.

El grado de asociación entre el consumo de amaranto en sus diferentes presentaciones en relación con la ocupación, fue positiva moderada. Además, la correlación fue significativa en el nivel 0,01 con un examen estadístico unilateral. De igual forma el nivel de ingreso y la cantidad que se consume resultó positiva y alta. Las asociaciones entre el nivel de ingreso y el precio que está dispuesto a pagar son positiva y alta, de igual forma, los años de estudio, el precio que está dispuesto a pagar resultó positiva y alta. El nivel de ingreso es un factor que influye en la frecuencia y la cantidad que se consume. Las personas que estudian o trabajan, son un nicho de mercado, están dispuestas a consumirlo en el desayuno o como snack.

Asimismo, investigaciones recientes muestran la versatilidad que tiene el amaranto para la obtención de microcápsulas o ciclodextrinas a partir del almidón que contiene y que es de relevancia para la industria alimentaria y farmacéutica, ya que en ellas pueden introducirse vitaminas, minerales $\mathrm{y}$ antioxidantes, además de que conservan aromas y sabores y estabilizan medicamentos (ArceVázquez, Ponce-Alquicira, Delgado-Fornué, 
be published and spread so amaranth can be included in the Mexican diet and stop being consumed only as bars, which is the traditional form in Mexico.

End of English version

\section{REFERENCES / REFERENCIAS}

Alejandre, I., G., Valdés, L. C. G. S., \& García, P. J. (2012). Selección y adaptación de variedades criollas de amaranto (Amaranthus cruentus L.) en el Noreste de México. In: Espitia Rangel E. (ed). Amaranto: Ciencia y Tecnología. Libro Científico No. 2. INIFAP/ SINAREFI. México, pp 249-256.

Arce-Vázquez, M. B., Ponce-Alquicira, E., Delgado-Fornué, E., Pedroza-Islas, R., Díaz-Godínez, G., \& Soriano-Santos, J. (2016). Integral use of Amaranth starch to obtain cyclodextrin glycosyltransferase, by Bacillus megaterium, to produce $\beta$-cyclodextrin. Frontiers in microbiology. 7:1-11.

Ashwell, M. 2002. Concepto sobre los alimentos funcionales. ILSI (International Life Sciences Institute). ILSI Europe. Bélgica. pp. 48.

Ayala, G., A. V., Escobedo, L. D., Cortés, E. L., \& Espitia, R. E. (2012). El cultivo del amaranto en México, descripción de la cadena, implicaciones y retos. In: Espitia Rangel E. (ed). Amaranto: Ciencia y Tecnología. Libro Científico No. 2. INIFAP/SINAREFI. México, pp. 315-330.

Ayala, G., A. V., Espitia, R. E., Rivas, V. P., Almaguer, V. G., \& Preciado, R. P. (2016a). Análisis del sistema productivo de amaranto en Temoac, Morelos, México. Ciencia Ergo Sum, 23: 49-57.

Ayala-Garay, A. V., Espitia-Rangel, E., Rivas-Va-
Pedroza-Islas, Díaz-Godinez, \& SorianoSantos, 2016).

\section{CONCLUSIONES}

La producción de amaranto en México ha mostrado un crecimiento dinámico que se explica fundamentalmente por el incremento en la superficie sembrada y con escasa aplicación de innovaciones que incrementen los rendimientos por unidad de superficie.

Las personas que estudian o trabajan, son un nicho mercado importante para los productos elaborados a partir de amaranto, generalmente están dispuestos a consumirlo en el desayuno o como snack, pagar precios de $\$ 20.00$ hasta $\$ 51.00$ y que estén accesibles en tiendas locales, supermercados y puestos ambulantes principalmente. El sabor y la calidad son factores que deben estar presentes en la elaboración de los productos de amaranto, a pesar de que la alegría (golosina) es el producto de mayor consumo, también los encuestados están interesados en los productos alimenticios a partir del amaranto.

El consumo de amaranto no depende del conocimiento del consumidor sobre que es un alimento funcional que contribuye a mejorar su bienestar, ya que solo $35 \%$ de los consumidores conoce sus propiedades. El nivel de ingreso sí es un factor que influye en la frecuencia y la cantidad que se consume.

Existe desconocimiento en la población de la diversidad alimenticia del amaranto, 
lencia, P., Martínez-Trejo, G., \& Almaguer-Vargas, G. (2016b). Análisis de la cadena del valor de amaranto en México. Agricultura Sociedad y Desarrollo. 13: 87-104.

Barrón-Yáñez, M. R., Villanueva-Verduzco, C., García-Mateos, M. R., \& Colinas-León, M. T. (2009). Valor nutricio y contenido de saponinas en germinados de huauzontle (Chenopolium nuttalliae Saff.), calabacita (Cucurbita pepo L.), canola (Brassica hapus L.) Revista Chapingo. serie horticultura. 15(3), 237-243. Recuperado el 11 de noviembre de 2019, de http://www.scielo. org.mx/scielo.php?script=sci_arttext\&pid=S1027-152X2009000500003\&In$\mathrm{g}=\mathrm{es} \&$ tlng=es.

Brambila, P., J. J. (2011). Bioeconomía: instrumentos para su análisis económico. SAGARPA-COLPOS. 1ra edición. pp. 305.

CONACYT (Consejo Nacional de Ciencia y Tecnología). (2016). Universidad Autónoma de Querétaro (UAQ). Programa Intensivo de Ingeniería para la Innovación del Centro Académico de Desarrollo e Innovación de Productos (CAIDEP). http://www.conacytprensa.mx/index.php/ciencia/salud/9503-innovan-en-alimentos-saludables (Consulta: noviembre 2017).

CONEVAL (Consejo Nacional de Evaluación de la Política de Desarrollo Social). (2017). Evolución de la pobreza por la dimensión de ingreso en México 1992-2016. http:// www.coneval.org.mx/Medicion/Paginas/ Evolución-de-las-dimensiones-de-pobreza.aspx (Consulta: noviembre de 2017).

Cortés, R., M., Chiralt, B. A., \& Puente, D. L. (2005). Alimentos funcionales: una historia con mucho presente y futuro. Vitae. 12.5-14. lo que incide en un desaprovechamiento integral de la planta, ya que puede prepararse como postre, sopa, ensalada, atoles, panques, y además combinar su harina con soya o maíz e incrementar el nivel proteínico de los alimentos.

El amaranto como tradicionalmente se consume, que es en palanqueta, se compra de manera informal. Se vende sin etiqueta y, por tanto, no se conoce la forma e ingredientes de elaboración, mientras que en un establecimiento formal llevaría etiquetado y se incluiría la información respectiva del etiquetado de acuerdo con la Norma Mexicana NMX-116-SCFI2010 de amaranto.

Además, se requiere de una estrategia transversal institucional que fomente el cultivoyconsumo del amaranto en México, destacando que, así como es tolerante a sequías para su cultivo y producción, también es un alimento funcional que además de nutrir, nos previene de ciertas enfermedades por su alto contenido de aminoácidos esenciales y su contenido de péptidos bioactivos.

La información sobre las propiedades nutricionales $\mathrm{y}$ funcionales se debe publicitar o divulgar, para que el amaranto se incluya en la dieta del mexicano y deje de ser consumido solo como palanqueta, que es la forma tradicional en México.

Fin de la versión en español 
DOF (Diario Oficial de la Federación). (2010). Declaratoria de vigencia de la Norma Mexicana NMX-FF-116-SCFI-2010 "Productos agrícolas destinados para consumo humano-grano reventado de amaranto (Amaranthus spp.) para uso y consumo humano-especificaciones y métodos de ensayo". http://dof.gob.mx/nota_detalle. php?codigo $=5155027 \&$ fecha $=12 / 08 / 2010$ (Consulta: noviembre 2016).

DOF (Diario Oficial de la Federación). (2019). Acuerdo por el que se emiten las Reglas de Operación del Programa de Abasto Rural a cargo de Diconsa, S. A. de C. V. (DICONSA), para el ejercicio fiscal 2019. Disponible en: https://dof.gob.mx/nota_detalle.php?codigo $=5573581 \&$ fecha $=26 / 09 / 2019 \&$ prin $\mathrm{t}=$ true

Escalante, E. M. C. (2011). Rescate y revaloración del cultivo del amaranto. Instituto Interamericano de Cooperación para la Agricultura (IICA). 2010, Fondo CONACYT-SAGARPA, COFUPRO e IICA. $91 \mathrm{p}$.

Escobedo-López, D., Ayala, G. A. V., \& Campos, S. L. G. (2012). Formas de consumo del amaranto en México. In: Espitia Rangel E. (ed). Amaranto: Ciencia y Tecnología. Libro Científico No. 2. INIFAP/SINAREFI. México, pp.: 341-354

Gómez, O. L. (1994). La Política Agrícola en el Nuevo Estilo de Desarrollo Latinoamericano. Organización de las Naciones Unidas para la Alimentación y la Agricultura. Santiago, Chile. 675 p.

González, A. O., Reyes H. J., Gaytán H. D., Campos C. C. I., \& Palos L. A. G. (2018). Atole de amaranto y su efecto potencial sobre la composición corporal de adultas mayores. Nutrición clínica y dietética hospitalaria. 38(2): 114-119. DOI:1012873/ 382ogonzalez
Huerta-Ocampo, J. A., Maldonado-Cervantes, E. \& Barba, R. A. P. (2012). Amaranto: propiedades benéficas para la salud. In: Espitia Rangel E. (ed). Amaranto: Ciencia y Tecnología. Libro Científico No. 2. INIFAP/ SINAREFI. México, pp. 303-312

INEGI (Instituto Nacional de Estadística y Geografía). (2015). Encuesta Intercensal 2015. http://www.beta.inegi.org.mx/proyectos/ enchogares/especiales/intercensal (Consulta: julio 2016).

Jacobsen, S. E., Iteno, K., \& Mujica, Á. (2002). Amaranto como un cultivo nuevo en el norte de Europa. Agronomía Tropical 52: 109-119.

Martínez, O., R. M., Tuya, P. L. C., Martínez, O. M., Pérez, A. A., \& Canovas, A. M. (2009). El coeficiente de correlación de los rangos de Spearman, caracterización. Rev. Haban cienc méd La Habana, Vol 8.19 p.

Morales G., J. C., Vázquez, M. N., \& Bressant, C. R. (2009). El amaranto: características, físicas, químicas, toxicológicas y funcionales y aporte nutricio. Instituto Nacional de Ciencias Médicas y nutrición Salvador Zuribán.

Paredes L., O. (1994). Amaranth: biology chemistry and technology. CRC. Press Boca Raton, Fla. 270 p.

Paredes, L., O., \& Valverde M., E. (2006). Los recursos nutracéuticos y medicinales que Mesoamérica le ha dado al mundo. Revista CINVESTAV. pp.:65-73.

Repo-Carrasco, R., Espinoza, C., \& Jacobsen S., E. (2001). Valor nutricional y usos de la quinua (Chenopodium quinoa) y de la kañiwa (Chenopodium pallidicaule). In: Jacobsen S-E., Z. Portillo (ed). Primer Taller Internacional sobre Quinua - Recursos Genéticos y Sistemas de Producción. UNALM Lima, Perú. pp.: 391-400. 
Rocandio, P., A. M., \& Arroyo I., M. (2000). Alimentos funcionales en Europa. Revista Clínica Española. pp.: 260-261.

Rojas, S. R. (2002). Guía para realizar investigaciones sociales. Plaza y Valdés. México. $437 \mathrm{p}$.

Sánchez, K., \& Navarrete, E. (2018). Amaranto en México: viejas estrategias productivas y nuevos consumidores. Investigaciones Sociales, 21(38), 45-58. https.//doi. org/1015381/is.v21¡38.14213.

SIAP (Sistema de Información Agroalimentaria y Pesquera). (2017). http://nube.siap.gob. mx/cierre_agricola (Consulta: julio 2017).

SIAP (Sistema de Información Agroalimentaria y Pesquera). (2015). Atlas Agroalimentario 2015. http://nube.siap.gob.mx/publicaciones_siap/pag/2015/Atlas-Agroalimentario-2015 (Consulta: julio 2017).

SIAP (Sistema de Información Agroalimentaria y Pesquera). (2016). Atlas Agroalimentario
2016. http://nube.siap.gob.mx/publicaciones_siap/pag/2016/Atlas-Agroalimentario-2016 (Consulta: julio 2017).

SIAP (Sistema de Información Agroalimentaria y Pesquera). (2018). Atlas Agroalimentario 2018. http://nube.siap.gob.mx/publicaciones_siap/pag/2016/Atlas-Agroalimentario-2018 (Consulta: noviembre 2019).

Siró, I., Kápolna, E., Kápolna, B., \& Lugasi, A. (2008). Funtional food. Product development, marketing and consumer acceptance-A review. Appetite. 51: 456-467.

Suárez Algara, Gallegos Martínez, \& Reyes Hernández (2013). Amaranto: efectos en la nutricion y la salud, Tlatemoani, issue 12, https://EconPapers.repec.org/ RePEc:erv:tlatem:y:2013:i:12:14.

Tennina, L. 2014. Alimentación inteligente: Comer para pensar, pensar para comer. Edit Grijalbo. 202 p. 
